\title{
The Importance of Character-Based Health Education in School to Improve Quality of Health Living in Indonesia
}

\author{
Agustinus Hermino ${ }^{1} \&$ Dwi Sogi Sri Redjeki ${ }^{2}$ \\ ${ }^{1}$ Department of English Education, Faculty of Humanities, Sari Mulia University, Banjarmasin, Indonesia \\ Correspondence: Agustinus Hermino, Department of English Education, Faculty of Humanities, Sari Mulia \\ University, Jalan Pramuka Nomor 2, Banjarmasin, South Kalimantan, Indonesia. E-mail: \\ agustinushermino@unism.ac.id
}

Received: June 4, $2020 \quad$ Accepted: September 9, $2020 \quad$ Online Published: September 24, 2020

doi:10.5539/ass.v16n10p25

URL: https://doi.org/10.5539/ass.v16n10p25

\begin{abstract}
The purpose of this research is to provide an understanding of the importance of character-based health education that aims to provide an understanding of teachers and parents who act as educators at school and at home about positive habits for a clean and healthy life, both for themselves and the environment. Method, this research is carried out by conducting academic analysis from various aspects of relevant reference sources so as to find new theoretical meaning in order to answer the challenges that occur in society. Result, Character-based health education can be taught through internalization methods by prioritizing modeling, habituation, rule enforcement, and motivation. Thus, character-based health education can be done intra curricular or extracurricular. Intra curricular is integrated into the subjects, while extracurricular are done outside of class hours, all of which can be done through example, instilling discipline, habituation, creating a conducive atmosphere and integration-internalization. In addition, collaborative communication between parents and teachers to children or students will bring students to the development of good and strong character of the importance of healthy living and healthy living that will support the achievement of a good future.
\end{abstract}

Keywords: health education, character-based health education, healthy life

\section{Background}

Based on data submitted by the Ministry of Health of the Republic of Indonesia, up to May 10, 2020, Indonesian citizens who were positively infected with Covid-19 became 14,032. Of the total 973 people have been declared dead and 2,698 people have been declared cured. With the increasing number of cases of corona virus infection, the central and regional governments have issued appeals and policies to prevent the spread of this virus. Large-Scale Social Restrictions (LSSR) policies have now been established in various regions in Indonesia.

At present the number of people infected with the corona virus has reached more than four million people worldwide. The mortality ratio which at the beginning of the pandemic "only" reached around $3 \%$ has now gone up to around $6 \%$. Corona virus is no longer a disease that can be underestimated, therefore all people in the world need to be really vigilant.

Until now, various attempts have been made by the Indonesian government at the central and regional levels to curb the rate of transmission, starting from the introduction of the LSSR, increasing the number of PCR Covid-19 examinations, to the construction of emergency hospitals. Many people have also begun to realize to protect themselves by wearing masks and restricting going out of the house, although some still do not heed the appeal.

Although there are no signs of completion until now, with the efforts of the government and the community, the transmission of the corona virus has become a little more controlled. This can be reflected in the number of patients who have been cured, which are increasing every day.

Services for conducting Covid-19 tests through rapid tests and PCRs with swabs are increasingly widely available, especially for people who must continue to work in the midst of a pandemic. Even so, for people who have been through the examination and the results are negative, it does not mean that these people can relax without doing the applicable health protocols. Keep running the existing appeals, so that the wider community can still be protected from the corona virus. 
On March 11, 2020, the United Nations World Health Organization, the World Health Organization (WHO), made a statement that given the situation, corona virus infection was in the pandemic category. Pandemic is the highest disease spread category, above the epidemic. An epidemic is a high number of diseases in a certain area, but does not spread widely to other areas. If an infection starts to spread widely even throughout the world with a rapid spread, then the condition is called a pandemic.

Since hundreds of years ago, the world has experienced several pandemic periods. The pandemic that caused the greatest number of victims was the Spanish Flu which occurred in 1918. Finally, the WHO stated the existence of a pandemic situation was in 2009 when swine flu cases spread. World health researchers warn the situation of the corona virus transmission (COVID-19) in Indonesia could overwhelm the government. In fact, in the worst case scenario, Indonesia could potentially be the center of a new spreading corona pandemic in Asia. Limited facilities and medical personnel in Indonesia also contributed to the possibility of opening the worst possible risk. So far Indonesia has become the country in Southeast Asia with the highest percentage of deaths related to corona virus infection.

Based on data on Wednesday, March 25, 2020, there were 58 deaths from 790 positive COVID-19 case findings in Indonesia. The percentage of corona virus patient deaths in Indonesia reached 7.34 percent, surpassing Malaysia with a fatality rate of 1.05 percent, the Philippines (5.05 percent), and Thailand ( 0.42 percent)

Based on the description above, it is very important for the awareness of health for the wider community regarding the spread of this corona virus and more importantly is self-discipline of each person so that there is a collective discipline to break the chain of spreading of this corona virus.

\section{Method}

The purpose of this academic paper is to give an appropriate information regarding the most important of healthy life awareness and individual discipline for the community in Indonesia based on all research in health community, literature review, and academic opinion from researcher. As stated by Creswell (2009), McAlpine \& Admunsen (2011), Arifin \& Hermino (2017) that appropriate academic opinion from researcher that able to give an impact to the community have to be based on relevant previous research and relevant literatures review.

\section{The Importance of Character-Based Health Education}

From an etymological perspective, the word "character" comes from the Greek word "charassein", in Webster's New World Dictionary of the American Language, "character" is interpreted as "a pattern of individual moral behavior." Therefore, character-based health education can be defined as an effort to form an individual's moral behavior patterns to live healthily from both physical and spiritual aspects through a continuous process. Therefore the most important character-based health education is actually given to a child, from an early age, in the smallest but most important educational institution, namely the family. Within the scope of the family, a child will be given an understanding of the meaning of health and moral character patterns or behavior can be formed by parents consisting of fathers and mothers.

Besides the family, there are educational institutions that can be involved by parents to instill an understanding of the importance of health in growth and development through good character in their children. The intended educational institution is a school. As a formal educational institution, schools ranging from initial education to higher education are required to shape the character of each student. This is because the school is a partner of parents in educating their children to form personality patterns, behaviors, traits, traits, and character.

Therefore character-based health education is an active effort to equip knowledge about health, instill a love of the importance of a healthy life and form healthy living habits in accordance with the values, norms, culture, and religion that is embraced, as well as promoting a series of attitudes, behaviors, motivations and skills will understand the importance of healthy living. With this good understanding, character-based health education can shape the personality that characterizes healthy living and healthy behavior in accordance with the characteristics, style or characteristics of a person that comes from the formations received from the environment (acquired) and one's innate soul from birth (iborn).

Character-based health education is education that provides an understanding of the importance of a healthy life based on the depth of character, which involves aspects of knowledge, feelings, and actions to be able to continuously apply and practice consciously about the importance of a healthy lifestyle.

Building the character of health education needs to be done comprehensively, not only through formal education, but also through non-formal education. In this regard, it requires 11 principles so that character-based health education can run effectively, such as: 1) developing the basic meaning of healthy living and healthy living as a foundation; 2) comprehensive character definition which includes thoughts, feelings and behavior; 3) use a 
healthy lifestyle approach that is comprehensive intentional and pro-active; 4) create a school community that is attentive to the importance of healthy living; 5) gives students the opportunity to take concrete actions as an application of a healthy lifestyle; 6) create an applicable academic curriculum in the health field; 7) fostering student motivation to be able to practice healthy living patterns; 8) involve school staff in the application process of implementing a healthy lifestyle in the school environment; 9) foster a healthy lifestyle together; 10) involving families and community members as partners; 11) evaluating the character of the school, the function of school staff as character educators and the extent to which students manifest characters well.

With the character-based health education implemented systematically and continuously, a child will become emotionally intelligent. This emotional intelligence will become an important provision in preparing children for the future, because someone will be easier and more successful face all kinds of life challenges, including challenges to succeed academically (Tuan, 2020). Character-based health education has come to the attention of various countries in order to prepare a quality generation, not only for the interests of individual citizens, but also for citizens as a whole. Character-based health education can be interpreted as the deliberate us of all dimensions of school life to foster optimal character development or it can be interpreted as a deliberate effort of all dimensions of life in school to help the formation of characters optimally.

The purpose of character-based health education is to teach the values of the meaningfulness of aspects of health in general for daily life by prioritizing local cultural values, government rules, and broad norms that can be accepted as a foundation for good and responsible behavior. The whole meaning is also described as moral behavior. If this meaning can be implemented well and measurably then health factors in Indonesia can significantly contribute to improving the quality of human resources and also contribute to strengthening the existing education system, including the existence of healthy young people physically and spiritually.

In connection with the above, the learning strategy with regard to: (a) moral knowing will prioritize inquiry-based learning that focuses on the sense of empathy for the conditions that are happening around the environment; (b) moral loving will prioritize the occurrence of patterns of interaction and communication in a balanced manner between students and students, as well as students and teachers; and (c) moral doing will use more individual approaches through mentoring in utilizing potentials and opportunities in accordance with the students' environmental conditions. The three learning strategies are systematically designed so that students and teachers can take advantage of all the values and morals that are in accordance with the potential and opportunities available in their environment and can begin to be encouraged to grow in the awareness of the importance of healthy living and healthy living as well.

Thus, the result of learning is the formation of habits of thinking, acting, and behaving in a healthy manner in the sense that students have the knowledge, willingness and skills in doing good that puts forward the awareness of the importance of healthy living both physically and mentally. Through this comprehensive understanding it is expected to be able to prepare patterns of management of character-based health education learning that can produce students who have strong character in the sense of having resilience in science, faith, and pious behavior, both personally and socially.

\section{Focus on Character-Based Health Education}

There are three focuses of character-based health education in the current era of globalization that need to be interpreted properly, namely: first, health education which focuses on teaching (teaching values), where the learning aspect puts forward the inculcation of values of the importance of health academically and implementation healthy living in daily practices ranging from healthy for oneself, healthy for others, healthy for the environment and healthy for living together in the wider community. Second, health education which focuses on value clarification, where the teacher's explanation aspects will be very important because they must provide an explanation of the aspects that are feasible and inappropriate, right or not right. This process is an experiential learning so that good experience and/or good learning from teachers will be very useful in explaining to students. Third, health education which uses a moral growth approach (character development), where collaboration between the role of teachers and parents becomes very important because communication between the two will be very helpful for the growth of awareness of the importance of living healthy and healthy living both at home and school. Collaborative communication and collaboration of attention between teacher and parent to the child will make the child's soul grow in positive and healthy attention.

This is also in line with what was stated in research by Cavel (2010) that the understanding of the importance of healthy living and healthy living needs to be embedded as the values of character education centered on teaching which prioritizes the contents of the meaning of health meaning literally and applicable to be explained and studied, so that it can become a set of quality virtues morals that are known and understood by students, where 
value clarification prioritizes the process of moral reasoning and the selection of values that students must have.

Furthermore, Lie (2018) and Lickona (1991) also suggested that the focus of strengthening the growth and development of strong characters for children is on the growth of moral character that prioritizes behavior to reflect the acceptance of values and emphasize the elements of motivation, and aspects of relative personality stable which will direct individual actions. The first focus prioritizes knowledge and understanding (intellectual), the second focus, prioritizing behavior (conduct), but still they give priority to understanding, as well as the process of forming and selecting values. While the third focus prioritizes the growth of internal motivation in shaping values in harmony with the stages of individual moral development.

In line with the above, Kaswardi (1993), Thurber \& Walton (2012) also stressed that character or character is taught through internalization methods by prioritizing exemplary, habituating, enforcing regulations, and motivating. Thus, character-based health education can be done intra curricular or extracurricular. Intra curricular is integrated into the subjects, while extracurricular are done outside of class hours, all of which can be done through example, instilling discipline, habituation, creating a conducive atmosphere and integration-internalization.

Whole and comprehensive character-based health education offers several alternatives to develop virtues to establish a healthy person both physically and spiritually and to have an individual character become a person of priority. The choice of priority is based on three dimensions, namely the individual dimension, the social dimension, and the moral dimension. First, the individual dimension. In this dimension, it emphasizes the importance of understanding healthy living and healthy living based on things that have been informed by parents at home or at school. This individual understanding will be a good habit where each child will be able to live a healthy lifestyle independently. Second, the sausage dimension. This dimension can run well if the individual dimension has been running properly, where the habit of clean and healthy lifestyle which has been routinely carried out independently will continue to continue in the social environment so that it can become an embryo for the habit of healthy living and communal healthy living. Third, moral dimension. With the passage of the two previous dimensions then the next will be a moral movement for healthy living and healthy living. The moral dimension emphasizes the importance of: 1) respect for physical and spiritual health; 2) respect for good habits and good examples; 3) transcendental and academic excellence; 4) self-mastery and empathy; 5) courage and responsibility; 6) skilled and democratic; 7) respect for differences and local wisdom; and 8) moral integrity.

In the effort to implement the three dimensions as explained earlier, there are three designs for the implementation of character-based health education, such as: first, the design of health education by prioritizing habituation in the classroom at school. This design is based on the relationship of teachers as educators and students as learners in the classroom. The context of health education is the relational process of class communities in the context of learning. The teacher-student relationship is not a monologue, but a dialogue with many directions because the class community consists of teachers and students who are both interacting with the material. Providing understanding and understanding of the virtues of healthy living and proper healthy life, including non-instructional domains, such as classroom health management, class consensus on healthy living, comfortable learning atmosphere and healthy living corridors.

Second, design health education by mainstreaming school culture. This design builds a school culture based on values and norms embedded in schools that are able to shape the character of students with the help of school social institutions so that certain values are formed and formed within students. To instill the moral value of healthy living and healthy living is not enough just to give moral messages to students. This moral message must be strengthened by the creation of a culture of habituation through the establishment of strict and consistent school rules for culture for a clean and healthy life.

Third, design health education by mainstreaming healthy living habits in the community. In educating, the school community does not struggle alone, but people outside educational institutions, such as families, the general public, and the state, also have a moral responsibility to integrate the formation of healthy lifestyles and healthy lives on the basis of character in the context of their lives, so that meaning character can be swallowed well because of the support of commitment from the wider community and carried out simultaneously and synergistically. This communal awareness will have an impact on the habituation of healthy lifestyles in all aspects which will also strengthen the quality of its human resources.

\section{Strategic Character-Based Health Education}

a. Implementation Teacher as Role Model

In the character-based health education process, the teacher's position occupies a very central position, because 
through the teacher's role the process of transforming the values of the meaning of healthy living and healthy living can be explained and carried out. Thus, in the character-based health education projections, the main initiator should start with parents in their daily lives at home, which are then communicated to school teachers as collaborative collaborative efforts. Thus, teachers need to make a healthy habituation by themselves first through the routine process as a character itself before appearing to position themselves as educators to their students (Slavin, 2006). In this case the competency that must be possessed by a teacher is the ability to teach and teach to the maximum followed by personality competence as an educator to deliver students the character of the importance of a clean and healthy lifestyle well.

The reality that occurs in the world of education at the present time is the exemplary crisis among students, where teachers are unable to position themselves as significant people and role models, moreover unable to take on the roles and responsibilities as parents when at school. As a result, students adopt or take figures outside the world of education, such as singers, film stars, and non-religious figures as role models in behavior. So naturally then students are very easily immersed into behavior and character deviating from religious, social, and cultural norms. When parents and teachers are unable to portray themselves as role models in the process of transforming character and personality, then students who get the wrong role models, what happens is split personality in students which then leads to the process of alienation psychological to them.

It could be that the phenomenon of life without prioritizing the meaning of health, moral decadence that occurs among students is actually triggered by the inability of parents and teachers to transform the values of healthy living on the basis of character development to students. Thus, if character-based health education becomes the main stream in national education, it should be done first by preparing professional teaching staff who have good personalities and characters, so that later they can become role models for students or students. Not to forget, students who are interested in becoming educators or teachers must be able to create themselves as future teacher candidates who deserve to be "innocent and emulated". Emulated means to follow and obey everything he says. Being imitated means to copy everything you do and what your teacher does.

Teachers as role models should indeed be a source that inspires and motivates students. This means that when the teacher is a profession he must act as a professional, meaning that when the teacher carries out the task, he not only teaches the class routinely, but also educates, guides, directs, trains and evaluates Wannamaker (2013). The exemplary approach of all parties is a means that facilitates the formation of the character of the nation's children. Without a role model, character cannot be developed properly and the presence of a role model by a character teacher is the main key in character education (Wu, 2015; Upright, 2002).

\section{b. Character-based Health Education Learning Innovation}

In addition to the strategic role of teachers in the character-based health education process, a revolution in teaching is also needed. As Santoso (1981); Lickona (1991) have pointed out, that an educational learning model that promotes character values for the creation of a healthy life physically and spiritually requires moral knowledge, religion and characters that move synergistically.

With this learning paradigm, what is emphasized by educators is the mastery of the material based on the learning of healthy life experiences and healthy life that is practiced directly by the teacher in collaboration with the role of parents will be available and the absorption of students or practical memorization is more important. This practice is clearly illustrated in the daily models of teachers and also the habit of healthy living by family members in the home that will be able to act as lighters for the growth and development of healthy living not only from the aspect of advice by teachers and parents but also directly into the realm of practice that will be more easily understood by students or students.

The creation of this humanities learning model will greatly help students to better absorb easily what should be done and what should be avoided, as well as the awareness will bring students to understand the meaning of the paradigm of health education academically and practically on the basis of character directed at the will and motivation, and not mere intellect.

\section{c. Evaluation Character-Based Health Education}

As for the problems that sometimes appear or appear confusing when talking about the character to be evaluated, namely about the manner and purpose of the evaluation. Character education is often seen as a difficult field to measure, assess and evaluate because it has to measure or assess students' knowledge about the meaning of healthy living and healthy living from both academic and practical aspects, and this sometimes raises stigma through written tests will be easier than assess student behavior. There are serious issues relating to ways of assessing character-based health education. 
Evaluation problems are often associated with the goals of character-based health education itself. Should the evaluation be related to grade promotion, or graduation, as has been recommended by the government, where assessment of character, behavior, attitude, can be a reason for not raising or graduating students? In fact, a summary assessment criterion like this is often just a paper type, and does not occur in the field. As long as the child passes the national exam, the issue of character, morals, and student behavior can still be ignored.

Therefore, in the evaluation process, character-based health education not only stands alone in a subject, but the inculcation of character values can become a hidden curriculum in certain subjects whose base is humanities. Besides the process of inculcating character values and at the same time the evaluation process, it also cannot only be monopolized by the school, but also involves a synergistic role between parents at home, and teachers at school. In this case the teacher must also establish a good relationship with students' parents. This is as stated by Yarmohammadi et al. (2014) that the communication collaboration that is established between parents of students and teachers at school will increase confidence in children or students to be able to learn well, both from academic aspects and daily behavior.

\section{d. Teachers as Builders of Positive Self-Image of Children}

Many teacher behaviors that can "kill" the character of children, namely by making children feel inferior. A teacher who never gives praise or positive words, except scorn and negative words, will make students become insecure. Insecurity that has formed in early childhood will carry over into adulthood. The role of the teacher in building a positive teacher image in children is very large.

Being a teacher as a character educator is not enough just to equip them with a theory and a set of curriculum but also concerning how a teacher can become an idol for his students, so that every word and behavior of the teacher will be imitated by his students.

A successful character educator is one who can immerse himself thoroughly (thoughts and feelings) while teaching, can build personal relationships with his students, has effective communication skills, is able to manage his emotions well, and is able to liven up the atmosphere. Immersing yourself totally does require an attitude of dedication and love for the profession that is being lived. Lickona (1991) said that to build emotional relationships with students, a teacher must also be able to show that he too is a human who has feelings.

A good character educator is one who can provide exciting inspiration to his students so students can fall in love with virtue. The term "fall in love in goodness" or falling in love with virtue can be done in an inspiring way so that children are excited to always be good and better children all the time. Because love is a source of energy for us to be happy and happy to do good.

We are all educators to continue to sow the seeds of virtue even though we don't know how it will turn out. Wherever we go we always sow the seeds of virtue and do not think whether the seeds we sow will grow and also do not intend to enjoy the fruit or take shelter under it. At school, teachers need to teach character-based health education for several reasons, at least including: first, students do not always get character-based health education at home. Actually, character-based health education is the initial task of parents at home, because the meaning of health was first taught in a family environment. Parents who want their children to have good and strong health must be willing to provide time, energy, thoughts, and materials to make it happen. However, parents are sometimes busy working and do not have the opportunity to spend time with children. In addition, children who attend school until evening and have activities after school, make them spend more time with teachers than with parents.

Second, character-based health education can work well if all devices in the family and school build good relationships for the development of strong characters in children of the importance of healthy living and healthy living. When students interact with peers and teachers, a good relationship exists between them in the classroom. This relationship is not only very beneficial both socially and personally, but also enhances effective learning management in a comfortable environment.

Third, character-based health education can create a positive school environment. In classroom learning, discussion activities and other activities make schools have a positive atmosphere. Students interact with peers, and the student-teacher relationship strengthens. This condition allows the teacher to share life experiences. Fourth, character-based health education is easy to do because it does not have to spend several hours in class, but can be done in a healthy life routine starting from home as an aspect of habituation and then continuing at school in life with school members so as to create a good culture and habituation the importance of healthy living. Fifth, character education can change the world. Elementary school students will become adults in the future. They will form a society. It is important for them to become highly educated graduates, but even more 
important is the value that they will become citizens who live in the world in hospitality, mutual respect, cooperation with others.

Thus the teacher or educator needs to: 1) apply learning methods that involve students' active participation; 2) creating a healthy and conducive learning environment; 3) provide explicit, systematic, and continuous character education by involving aspects of knowing the good, loving the good, and acting the good; and 4) pay attention to the uniqueness of each student in using the learning method. It means that teachers/educators need to train and shape students' characters through repetitions so that character internalization is consistent.

It is in this learning process that intellectual and motor skills need to be developed, therefore teachers act as trainers for their students. Professional teachers can be seen from the teaching skills they have. Teaching skills possessed by the teacher can be seen from several indicators including: 1) the teacher as a guide and facilitator who is able to foster self learning in students; 2) have high interaction with all students in the class; 3) give examples, challenging work; with clear objectives; 4) develop learning activities and objectives based; 5) train students to be responsible for their work and have a sense of ownership and be independent in learning; 6) develop individual learning; 7) involving students in learning and completing tasks through inquiry-based learning, for example by giving good and analytical questions; 8) creating a positive and conducive learning environment; and 9) provide high motivation and pride.

By having these skills, the teacher's role is very important in the formation of strong and positive student character. The teacher also has a very vital and fundamental role in guiding, directing, and educating students in the learning process (Seefeldt, 2005). Because of their very important role, the existence of teachers is even irreplaceable by anyone or anything even with sophisticated technology. Educational tools and media, infrastructure, multimedia and technology are only media or tools that are only used as teachers' companions.

Therefore, when the teacher has to form students in order to have strong character, the teacher himself already has it, so students can emulate the behavior, attitudes, and ethics of the teacher that students can observe and see in their daily lives. Character teachers are teachers who have values and beliefs that are based on the nature and purpose of education and are used as moral strength in carrying out their duties as educators. Therefore, teachers with strong character have the ability to teach, and can also be an example for their students. So in forming students who have strong and positive character, the teacher must have strong character as well.

\section{Health Paradigm Strategy}

The paradigm develops as a result of synthesis in human awareness of information obtained both from experience or from research (Hermino, 2016; Hermino, 2015). In the development of health development policies in entering the global era for Indonesia, there has been a change in mindset and basic concepts of health development strategies in the form of a healthy paradigm. Previously health development tended to use the sick paradigm by emphasizing curative efforts towards Indonesian society.

Changes in the health paradigm and our experience in dealing with health problems in the past have forced us to review the priorities and emphasis of the program in an effort to improve the health of the population which will be the main actors and maintain the sustainability of development. To form humans

Indonesia is a healthy, productive-creative human resource, we must think and be somewhat different from what we are doing now. We need a re-orientation in strategy and approach. The basic paradigm shift and re-orientation that needs to be done is the paradigm or concept that originally emphasized healing in the form of medication and alleviating the burden of the disease changed towards efforts to improve the health of most people who have not fallen ill so that bias can contribute more to development.

Changes in the health paradigm which now emphasizes promotive-preventive efforts compared to curative and rehabilitative efforts are expected to be a turning point in government policy in dealing with population health, which means health programs that focus on fostering national health are not just healing diseases. Thus, each new breakthrough needs to be preceded by a paradigm shift to change old habits and ways of thinking. Future health efforts must be able to create and produce healthy, productive Indonesian human resources so that the obsession with health efforts must be able to deliver every population to have adequate health status.

Changes in the health paradigm if implemented can have quite a broad impact (Hermino, 2014). That is because the organization of existing health efforts, existing health service facilities, is a vehicle and supporting facilities for the implementation of health services oriented to efforts to cure disease, so as to support the implementation of a healthy paradigm oriented to proactive promotive-preventive efforts, community centered, active participation and community empowerment, then all existing vehicles and facilities need to be adjusted or even reformed including reforming activities and programs at the health education center. 
Health workers must be able to invite, motivate and empower the community, be able to involve cross-sectoral cooperation, be able to manage health care systems that are efficient and effective, able to be leaders, pioneers, development and healthy living models. In the formation and empowerment of the most important community is how to invite and encourage the community to be interested and responsible for their own health by mobilizing the financial resources available to them.

\section{Closing}

Character is a quality or strength of mental, moral, behavior, attitude, and personality of a person. Character is the key to success in one's life in the future. Character-based health education forms intelligent personalities and strong characters, and this can be applied to every subject that needs to be developed so that students become human characters.

All educators, adults and parents need to develop character values in themselves and have an important role in shaping student character. School, family and community have strong and positive character to be able to form children with character. They not only become educators and teachers for students, but they are able to be role models for students.

\section{References}

Arifin, I., \& Hermino, A. (2017). The Important of Multicultural Education in Schools in the Era of ASEAN Economic Community. Asian Social Science, 13(4). https://doi.org/10.5539/ass.v13n4p78

Cavell, T. A. (2010). Social Adjustment, Social Performance, and Social Skills: A Tri-Component Model of Social Competence. Journal of Clinical Child Psychology, 19(2), 111-122 https://doi.org/10.1207/s15374424jccp1902_2

Coleman, W. L., \& Garfield, C. (2004). Fathers and Pediatricians: Enhancing men's roles in the care and development of their children. Psychosocial Aspects of Child and Family Health, 113(5), 1406-1411. Retrieved from http://www.pediatrics.org/cgi/content/full/113/5/1406

Creswell, J. W. (2009). Research Design. Qualitative, Quantitative, and Mixed Method Approaches. Los Angeles: SAGE Publications, Inc.

Hermino, A. (2019). Komunitas Masyarakat dan Perawatan Kesehatan dalam Peningkatan Kualitas Hidup. Jurnal Dinamika Kesehatan, 10(1). https://doi.org/10.33859/dksm.v10i1.437

Hermino, A. (2016). ASEAN Economic Community in the Pespective of Transformational Leadership in School. International Journal of Education and Research, 4(6), 401-416. Retrieved from http://www.ijern.com/June-2016.php

Hermino, A. (2015). Pendidikan Karakter dalam Perspektif Psikologis Siswa Sekolah Menengah Pertama di Era $\begin{array}{lllll}\text { Globalisasi dan } & \text { Multikultural. } & \text { Jurnal } & \text { Peradaban, } & \text { 8, }\end{array}$ https://doi.org/10.22452/PERADABAN.vol8no1.2

Hermino, A. (2014). Kepemimpinan Pendidikan di Era Globalisasi. Yogyakarta: Pustaka Pelajar

Kaswardi, E. M. (1993). Pendidikan Nilai Memasuki Tahun 2000. Jakarta: Gramedia.

Kozier. (1995). Fundamental of Nursing: Concept, Process and Practice (4th ed.). Philadelpia: WB Saunders Company.

Li, S. (2018). A Case Study of International Students' Social Adjustment, Friendship Development, and Physical Activity. Journal of International Students, 8(1), 389-408. https://doi.org/10.5281/zenodo.1134317

Lickona, T. (1991). Educating for Character. How Our Schools Can Teach Respect and Responsibility. Massachusetts: Allyn and Bacon, Inc.

McAlpine, L., \& Amundsen, C. (2011). Doctoral Education: Research-Based Strategies for Doctoral Students, Supervisors and Administrators. New York: Springer. https://doi.org/10.1007/978-94-007-0507-4

Notoatmojo, S. (2007). Kesehatan Masyarakat, Ilmu dan Seni. Jakarta: Rineka Cipta.

Pacho, T. O. (2020). Impact of Globalisation on African and Its Implication to Education. Social Sciences, Humanities and Sustainability Research, 1(1). https://doi.org/10.22158/sshsr.v1n1p81

Panggabean, M. S. (2002). Manajemen Sumber Daya Manusia. Jakarta: Ghalia Indonesia.

Santoso, S. I. (1981). Pembinaan Watak Tugas Utama Pendidikan. Jakarta: Penerbit UI Press.

Sari, N. P. W. P., \& Manungkalit, M. (2019). The Best Predictor of Anxiety, Stress and Depression among 
Institutionalized Elderly. International Journal of Public Health Science, 8(4), 419-426. https://doi.org/10.11591/ijphs.v8i4.20359

Seefeldt, C. (2005). Social Studies for the preschool/primary child (7th ed.). Upper Saddle River, NJ: Pearson.

Slavin, R. E. (2006). Educational Psychology: Theory and Practice. Boston: Pearson Education, Inc.

Tuan, N. D. (2020). Opportunities to Access to General Education of Children Living in Poverty Families in Ethnic Minority in Vietnam Nowadays. Asian Social Science, 16(6). https://doi.org/10.5539/ass.v16n6p43

Thurber \& Walton. (2012). Homesickness and Adjustment in University Students. Journal of American College Health, 60(5). https://doi.org/10.1080/07448481.2012.673520

Upright, R. (2002). To tell a tale: The use of moral dilemmas to increase empathy in the elementary school child. Early Childhood Education Journal, 30, 15-20.

Wannamaker, C. (2013). The Meaning and Significance of Social Adjustment. The Journal of Health and Physical Education, 10(1), 12-54. https://doi.org/10.1080/23267240.1939.10622608

Wu, H.-P. (2015). International Student's Challenge and Adjustment to College. Hindawi Publishing Corporation Education Research International. https://doi.org/10.1155/2015/202753

Yarmohammadi, Amirsardari, Akbarzadeh, Sepidarkish, \& Hashemian. (2014). Evaluating the Relationship of Anxiety, Stress and Depression with Sleep Quality of Students Residing at the Dormitories of Tehran University of Medical Sciences in 2013. World Journal of Medical Sciences, 11(4), 432-438. https://doi.org/10.5829/idosi.wjms.2014.11.4.84272

\section{Copyrights}

Copyright for this article is retained by the author(s), with first publication rights granted to the journal.

This is an open-access article distributed under the terms and conditions of the Creative Commons Attribution license (http://creativecommons.org/licenses/by/4.0/). 